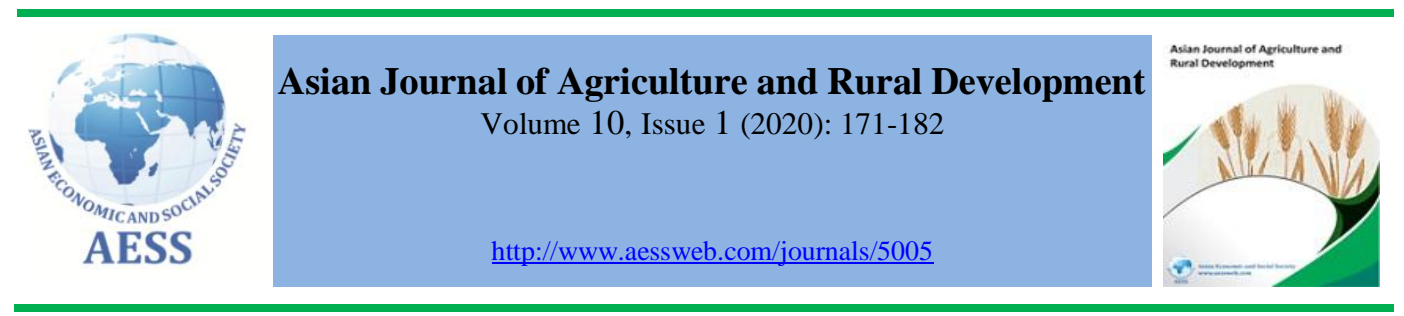

\title{
AN ASSESSMENT OF ECONOMIC SUSTAINABILITY IN BROILER ENTERPRISES: EVIDENCE FROM JORDAN
}

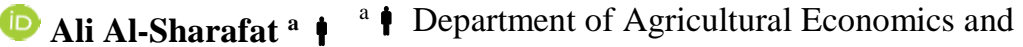

Bassam Al-Deseit ${ }^{\text {a }}$

Extension, Faculty of Agriculture, Jerash University, Jerash, Jordan

Motasem Al-Masad ${ }^{\text {b }}$ b Department of Animal Production and Protection, Faculty of Agriculture, Jerash University, Jerash, Jordan

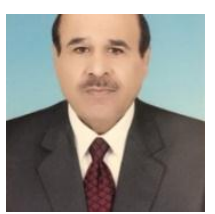

Corresponding author

$\checkmark$ a.alshorfaat@jpu.edu.jo (Corresponding author)

\section{ARTICLE HISTORY: \\ Received: 07-Jan-2020 \\ Accepted: 19-Mar-2020 \\ Online Available: 15-Apr- 2020}

\section{Keywords:}

Sustainability, Economic sustainability, Broiler, Jordan

\begin{abstract}
Assessing economic sustainability is crucial to measure livestock enterprise success. This study is aimed at assessing the economic sustainability of broiler enterprises in Jordan. To achieve the goals of this study, 94 broiler farms were surveyed. A multi-stage sampling technique, descriptive statistics, and simple economic analysis were adopted. The investigated farms' economic viability, which is the best indication for sustainability, is measured through profitability, liquidity and productivity indicators. The values of the economic sustainability indicators used in this study to assess profitability, liquidity, and productivity showed that the broiler sector in Jordan is economically viable and sustainable. Investors in livestock activities in Jordan are advised to invest in the broiler industry as it is with high economic sustainability.
\end{abstract}

\begin{abstract}
Contribution/ Originality
In Jordan, this is pioneer research in investigating the relationships between broiler farm profit and economic sustainability. Analyses concerning relationships between various sustainability components of the broiler industry in Jordan were conducted. The study adopted different indicators, which could not be overcome even by rigorous methods of analysis.
\end{abstract}

DOI: 10.18488/journal.1005/2020.10.1/1005.1.171.182

ISSN (P): 2304-1455/ISSN (E):2224-4433

How to cite: Ali Al-Sharafat, Bassam Al-Deseit and Motasem Al-Masad (2020). An assessment of economic sustainability in broiler enterprises: Evidence from Jordan. Asian Journal of Agriculture and Rural Development, 10(1), 171-182.

(C) 2020 Asian Economic and Social Society. All rights reserved. 


\section{INTRODUCTION}

According to the Jordanian Ministry of Agriculture (MoA), the Jordanian agricultural sector considered being one of the most important pillars of the country's economy. In 2018, the Agricultural Gross Domestic Product (AGDP), with a growth rate of 18\%, was around 1.6 billion Jordan Dinars (JDs) at current prices ( $1 \mathrm{JD}=1.4 \mathrm{USD}$ ). According to the Jordanian Department of Statistics (DoS) records agriculture contributed around 6\% of the Gross Domestic Product (GDP) of the country and around 18\% of the national exports in 2018 (DoS, 2018).

The Jordanian livestock sub-sector contributes, on average, about $60 \%$ of the agricultural output and provides a major source of income to many of the rural people. The broiler industry is a major component of the livestock sub-sector in the country. This industry supplied the country with about 209000 metric tons of broiler meat in the year 2018 with a self-sufficiency percentage of about $81 \%$ of this product (DoS, 2018). According to the DoS last agricultural census which (2017), broiler farms number of Jordan was of 1623 with a total capacity of around 29 million birds. Around 140 farms (almost $9 \%$ of broiler farms) in the country are with a capacity of more than 30,000 birds (DoS, 2017).

Based on Conway (2018), the total production of world broiler meat is estimated to be 122.5 million tons. Sustainable broiler production systems must depend on identifying production system which is suitable for broiler breeds despite major environmental, technical and economic constraints, and sustainable practices in broiler production should ensure system ability to maintain productivity (Kheiry, 2019). Investigating sustainability is largely related to the economic efficiency of farm activities. In low-sustainable or not sustainable farms, there is a significant increase in costs compared to returns (Bachev, 2017). All around the world, sustainability assessment of farming activities was investigated by many researchers (Bachev, 2017; Bachev, 2016; Bachev et al., 2016; Bastianoni et al., 2001; EC, 2001; FAO, 2013; Bachev and Petters, 2005; Fuentes, 2004; Andreoli and Tellarini, 2000; Sauvenier et al., 2005; UN, 2015 and Rigby et al., 2001). Bahri et al. (2019) stated that; "it is important to guarantee sustainable production of the broiler for present and future generation". Abdurofi et al. (2017) concluded that; "in meeting the expected higher demand for chicken meat, the broiler industry must operate sustainable production".

Sustainability dimensions are measured through many techniques (De Olde et al., 201a; 2016b). Farm economic sustainability among a large number of indicators has been developed (Werf and Petit, 2002). Complicated information is analyzed, quantified and simplified by indicators (Warhurst, 2002). Clearly understood results are produced by a useful indicator (Becker, 2004). Sustainability measures and indicators related to economic performance are widely used in farming sectors such as the broiler sector (Girardin et al., 2000 and Bélanger et al., 2012). In measuring the sustainability of livestock enterprises such as the broiler industry, several economic indicators can be used to investigate its viability (Moldan et al., 2012). To achieve the objectives of the present study, indicators related to profitability, liquidity, stability, and productivity were utilized.

In recent years a trend of completely integrated poultry farms was established in Jordan where the farms include hatcheries, feed plants, chicken houses, and slaughterhouses. This change in the poultry industry is a close relation to its sustainability, so it is very important to investigate the impact of this change. This study aimed at assessing the sustainability of the broiler industry in Jordan, as a major poultry sub-sector in the country, under the present situation of this industry. 


\section{WHAT IS AGRICULTURAL ECONOMIC SUSTAINABILITY?}

Agricultural sustainability is considered to be a crucial component of global sustainable development (Binder et al., 2010). More than 70 definitions for "Agricultural Sustainability were identified in the literature since the widespread of this concept in the 1980s (Zhen and Routray, 2003). FAO (2014) has defined sustainable agriculture as; "the management and conservation of the natural resource base, and the orientation of technological change in such a manner as to ensure the attainment of continued satisfaction of human needs for present and future generations. Sustainable agriculture conserves land, water, and plant and animal genetic resources, and is environmentally non-degrading, technically appropriate, economically viable and socially acceptable".

For agriculture to be sustainable the followings should be considered (Pretty, 1999):

- Natural processes should be included in the production process;

- Renewable resources utilization should be preferred while non-renewable resources utilization to be minimized;

- Farmers' self-reliance should be enhanced;

- Sustainable, profitable, efficient and long term levels of production to be guaranteed; and

Measuring agricultural sustainability is related to social, economic and ecological dimensions (Hayati et al., 2010). Agricultural sustainability assessments usually involve the evaluation of environmental sustainability, social sustainability and economic sustainability (Pope et al., 2004; Gómez and Sanchez, 2010). Brodt et al. (2011) stated that sustainable agriculture integrates environmental health, economic profitability, and social equity. He also reported that; "agricultural sustainability rests on the principle that we must meet the needs of the present without compromising the ability of future generations to meet their own needs". Brodt et al. (2011) also concluded that; "Social, economic, and environmental sustainability are closely intertwined and necessary components for truly sustainable agriculture". The following figure presents the three dimensions of sustainable agriculture according to Brodt et al. (2011).

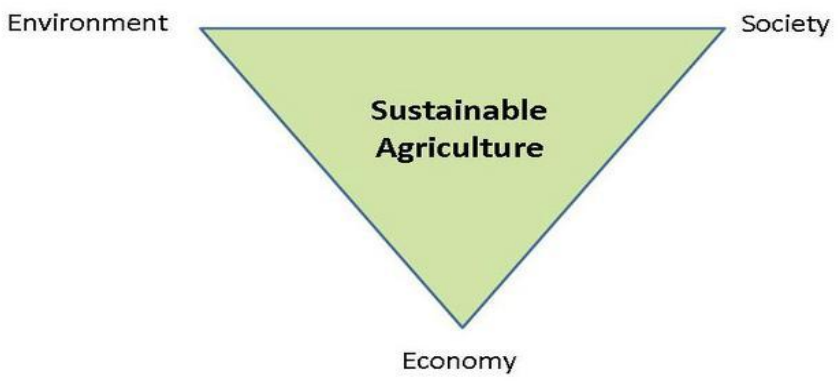

Figure 1: Dimensions of sustainable agriculture

Source: (Brodt et al., 2011)

An economically sustainable farm must meet the individual economic needs of farmers, farm families, and farmworkers. An economically sustainable farm allows financial stability and an acceptable economic return on used resources (Bachev, 2016). A sustainable farm manages all activities most economically. High costs and difficulties for the functioning are the results if the farm does not govern its activities (Bachev and Petters, 2005). Agricultural enterprises could be sustainable through its economy-related functions as well as its social and environmental related functions. The economic functions of agriculture include, among others, producing food and raw materials, achieving efficiency and effectiveness of production and sales, price competitiveness, 
providing a high quality of products and services and providing income (Wilkin, 2010 and Wrzaszcz and Zegar, 2016).

\section{MATERIALS AND METHODS}

\subsection{Data and sample}

The data and information utilized in this study were based on; First, secondary data sources as the (MoA, 2019) and its related Agricultural Directorates in the country, as well as the Department of Statistics (DoS). Second, a source of primary data includes a well-designed survey questionnaire. The information in the questionnaire was used to extract the basic economic sustainability indicators. The items in the questionnaire were directly related to the economic components of the input and outputs of the activities of the investigated farms (costs, revenues...). Balance sheets of the investigated farms were the major source for the values of the total assets and total liabilities of these farms.

A multi-stage sampling procedure was adopted in this study to select the sample from 1623 registered broiler farms in the country. The first stage was to stratify the farms in the country according to Northern, Middle and Southern provinces. The second stage was to select broiler farms with an average capacity of 30000 birds across the three provinces of the country. This capacity was selected because it is the most dominant one in the country. Finally, a simple random sampling was conducted to obtain the number of broiler farms which were administered with the survey questionnaire. The next step was collecting the data through the questionnaire. All of the above stages and steps were carried out during the period from July 1 to September 30, 2019. Based on the population of broiler farms in each province, sample distribution among the country is presented in Table 1. The sample size was determined according to the following formula (Yamane, 1967):

Where:

$$
n=[N] /\left[1+\left(N \times e^{2}\right)\right]
$$

$\mathrm{n}=$ Sample size (?).

$\mathrm{e}=$ Maximum tolerable error for the prevalence estimate (e.g. \pm 0.10 )

$\mathrm{N}=$ Population.

According to the above mentioned formula, the sample size is:

$\mathrm{n}=[1623] /\left[1+\left(1623 \times 0.10^{2}\right]\right.$

$\mathrm{n}=[1623] /[1+(1623 \times 0.01)]$

$\mathrm{n}=[1623] /[1+16.23]$

$\mathrm{n}=[1623] /[17.23]$

$\mathrm{n}=94$

Table 1: Provinces wise sample distribution

\begin{tabular}{lccc}
\hline Province & No. of Broiler Farms & \% of Broiler Farms & $\begin{array}{c}\text { No. of Farms in the } \\
\text { Sample }\end{array}$ \\
\hline Northern & 779 & $48 \%$ & $(0.48 \times 94)=45$ \\
Middle & 633 & $39 \%$ & $(0.39 \times 94)=37$ \\
Southern & 211 & $13 \%$ & $(0.13 \times 94)=12$ \\
Total & 1623 & $100 \%$ & 94 \\
\hline
\end{tabular}

Source: MoA and Researchers' computations

\subsection{Analytical techniques}

To achieve its goals, descriptive statistics and simple economic analysis were adopted in this study. The farm budgetary method was used in this study to compute indicators related to sustainability 
assessment. Descriptive statistics and budgetary techniques are very popular methods for calculating the cost of different input and return from the poultry business (Afzal and Khan, 2017). Sustainability involves future outcomes that cannot be observed at present. To achieve sustainability, agricultural enterprises should be able to maintain high efficiency of productionrelated directly to high economic viability. The problem of assessment of the sustainability of farms is directly related to the estimation of its economic viability. Farm economic sustainability is generally viewed as farm economic viability. Economic sustainability is defined as the economic viability of farming systems, i.e., their ability to be profitable (Gómez and Sanchez, 2010). So, the analysis of this study was related to the economic viability of the investigated farms. Farm economic viability, which is an indication of whether a farming system can survive in the long term is usually measured through profitability, liquidity, and productivity. Because calculations were conducted for one production cycle the Total Fixed Costs (TFC) were not included in computing the investigated measures.

\subsubsection{Profitability}

In assessing the sustainability of farm business profitability is one of the most important indicators. Profitability is the ability of an enterprise to achieve profit by utilizing its resources. In a farming business, such as broiler production, profitability indicators are used to evaluate the ability of a farm to produce maximum output (i.e. margin or profit), ideally with minimal input. Profitability indicators used throughout this study include gross margin and profitability ratios. Many studies are considered the gross margin and profitability ratios of an agribusiness as a sustainability indicator related to the business financial efficiency (Wrzaszcz and Zegar, 2016; Gómez and Sanchez, 2010; Moldan et al., 2012).

\subsubsection{Gross margin}

When using farm budgetary analysis the gross margin of an agribusiness is obtained by deduction of the total variable costs (TVC) from the total revenues (TR) obtained from selling broiler live weight. In the broiler industry, TVC is mainly the costs of day-old chicks, feed cost, house preparation costs, labor cost, veterinary costs, and miscellaneous costs. Gross margin formula is as follows:

$$
\text { Gross Margin }(\mathrm{GM})=\text { Gross Revenue }(\mathrm{GR})-\mathrm{TVC}
$$

The formula could be written as follows:

$$
\begin{gathered}
G M=\Sigma P Y-T V C \\
G M=G R-T V C
\end{gathered}
$$

Where:

$\mathrm{GM}=$ Gross margin (JDs)

$\mathrm{P}=$ Farm gate price/ $\mathrm{kg}$ of live weight (JDs)

$\mathrm{Y}=$ Total live weight $(\mathrm{kg})$

TVC $=$ Total Variable Cost (JDs)

\subsubsection{Profitability ratios}

For any farming business, the ability to generate profit could be evaluated by profitability ratios. These ratios indicate how well a farm is using its assets to generate profit. A higher profit ratio means the farm is performing well by generating revenues, profits, and cash flow. Profitability ratios used in this study include the benefit-cost ratio (BCR), the rate of return on investment (ROI) and the profitability index (PI). The formulas used to obtain these ratios are as follows:

$$
\begin{aligned}
& \text { BCR }=\text { Total Revenue }(\mathrm{TR}) \div \text { Total Cost }(\mathrm{TC}) \\
& \text { ROI }=\text { Gross Margin }(\mathrm{GM}) \div \text { Total Cost }(\mathrm{TC}) \\
& \mathrm{PI}=\text { Gross Margin }(\mathrm{GM}) \div \text { Total Revenue }(\mathrm{TC})
\end{aligned}
$$


Where:

TR $=$ Value of total live weight of birds (JDs)

$\mathrm{GM}=$ Gross margin (JDs)

TC $=$ Total costs incurred during production (TVC + Total fixed costs or TFC) in JDs. TFC are costs paid for permanent labor and housing.

\subsubsection{Liquidity}

Liquidity for any farm business is the availability of cash to meet immediate and short-term obligations of debt payments, taxes, and family living expenses. High liquidity produces flexibility for a farm in a low-risk position. Agribusiness's sustainability could be predicted using liquidity ratios. The most common measures of liquidity are the current ratio and working capital to gross revenue ratio. These two ratios were used in the present study.

\subsubsection{Current ratio (CR)}

$\mathrm{CR}$ is calculated by dividing the current farm assets (CA) by the current farm liabilities (CL). CR could be computed as follows:

$$
C R=C A \div C L
$$

In the broiler industry, current farm assets include cash and those items that farm can convert into cash in the normal course of business, usually within one production cycle. Current farm liabilities include those items that need to be paid within one production cycle. Commonly accepted ranges for CR include:

- Greater than 2 is strong

- $\quad 2$ to 1.3 would fall in the caution range

- Less than 1.3 would be weak

\subsubsection{Working capital to gross revenue ratio (WC/GR)}

Working capital to gross revenue ratio is used to determine the adequacy of working capital. The ratio measures the amount of capital the farm has with relation to the farm size. Working capital is calculated by subtracting total current farm liabilities from the total current farm assets. WC/GR is determined by dividing the Working Capital (WC) by Gross Farm Income or Gross Revenue (GR).

The ratio could be computed as follows:

$$
W C / G R=(C A-C L) \div G R
$$

Here, CL represents the current farm liabilities and CA represents the current farm assets. Commonly accepted ranges for this ratio include:

- Greater than $30 \%$ is strong

- $10 \%$ to $30 \%$ would fall in the caution range

- Less than $10 \%$ would be weak

\subsubsection{Productivity}

A general definition of productivity is the ability of production factors to produce the output. One of the commonest definitions of productivity is the ratio of output to input. It is generally measured as a partial productivity indicator which is a ratio of output to one input (Latruffe et al., 2008). Feed productivity $\left(\mathrm{P}_{\mathrm{f}}\right)$ and cost productivity $\left(\mathrm{P}_{\mathrm{c}}\right)$ indicators, as single-factor productivity measures, were used in this study to determine the average productivity of input used in broiler production in 
Jordan. These two well-known indicators were used in many studies related to farm business economics and sustainability measurement (Adeoti and Olawumi, 2013).

\subsubsection{Feed productivity}

To cope with their faster growth, broilers are fed special feeds. Feed plays a vital role in broiler production. It is the major cost of broiler farming which seriously affects the production output of the birds. $\mathrm{P}_{\mathrm{f}}$ is an important consideration for efficient and sustainable broiler farming. Feed productivity measures the average productivity of feed-in producing a certain quantity of broiler meat. The following formula was used to compute feed productivity:

$$
P_{f}=Y \div Q_{f}
$$

Where:

$\mathrm{P}_{\mathrm{f}}=$ Feed productivity

$\mathrm{Y}=$ Average output or average quantity of broiler meat produced (Tons)

$\mathrm{Q}_{\mathrm{f}}=$ Average quantity of feed consumed/ average output (Tons)

\subsubsection{Cost productivity}

Expenses that a firm face in producing a good or service are costs of production. Cost is considered to be the most significant determinant of the productivity of broiler farms. $\mathrm{P}_{\mathrm{c}}$ shows how efficiently farmers are using their available inputs in production. The following formula was used to compute cost productivity:

$$
P_{c}=Y \div A T C
$$

Where:

$\mathrm{P}_{\mathrm{c}}=$ Cost productivity

$\mathrm{Y}=$ Average value of output or average quantity of broiler meat produced

ATC $=$ Average total costs of production (JDs)

\section{RESULTS AND DISCUSSION}

The main financial items related to the financial indicators adopted in the analysis of the financial performance of the sampled broiler farmers in the present study were costs, returns, and cash flows. These items were determined based on market prices. The study delved into the economic sustainability of the broiler industry in Jordan. Profitability, liquidity and productivity measures for the 94 surveyed broiler farms were computed. The computing of these three measurements was based on data presented in Table 2. Calculations were conducted based on the following marketderived facts per one production cycle:

$-5 \%$ mortality rate.

- $\quad$ the average selling price of $1.28 \mathrm{JD} / \mathrm{kg}$ of live weight ( $1 \mathrm{JD}=1.4 \mathrm{USD})$

- average selling weight of $1.75 \mathrm{~kg} / \mathrm{bird}$

- average purchasing price of feed is $345 \mathrm{JDs} /$ ton $(4 \mathrm{kilograms} / \mathrm{bird} / \mathrm{cycle}=$

- one day old chicks price is $0.34 \mathrm{JDs} / \mathrm{chick}$ 
Table 2: Various statistics of broiler farms (30,000 birds)

\begin{tabular}{lc}
\hline \multicolumn{1}{c}{ Item and Explanation } & Average Value $($ JDs $)$ \\
\hline Average Variable Costs: & \\
Feed $[4 \times((30000-(0.05 \times 30000))] \times 345=(114 \times 345)$ & 39330 \\
Day-old chick $(30000 \times 0.34)$ & 10200 \\
Labor & 1440 \\
Medication and veterinary services & 450 \\
Miscellaneous (Electricity, Water, Cleaning and Sanitizing, Litter ...) & 900 \\
Average Total Variable Costs: & 52320 \\
Average Total Costs $($ ATC): & 52320 \\
Average Revenue $(28500 \times 1.75 \times 1.28)=(49875 \times 1.28)$ & 63840 \\
\hline
\end{tabular}

Source: MoA and Researchers' computations

\subsection{Profitability measures}

Gross margin and profitability ratios were used in this study to measure the surveyed broiler farms' sustainability. Table 3 shows the results of the analysis of these two measurements. The indicators of profitability ratios measure were the benefit-cost ratio (BCR), the rate of return on investment (ROI) and the profitability index (PI).

Table 3: Profitability measures analysis

\begin{tabular}{lcc}
\hline Measure & \multicolumn{1}{c}{ Indicator Formula } & Value (JDs) \\
\hline Gross Margin & TR - TC & $63840-52320=11250$ \\
Profitability Ratios: & & \\
& & \\
& Benefit Cost Ratio (BCR) $=$ TR $\div$ TC & $63840 \div 52320=1.22$ \\
& Rate of Return on Investment (ROI) $=$ GM $\div$ TC & $11250 \div 52320=0.215$ \\
& Profitability Index (PI) $=$ GM $\div$ TR & $11250 \div 63840=0.176$ \\
\hline
\end{tabular}

Source: Researchers' computations

Table 3 shows that the average value of the gross margin (GM) of the surveyed farms is 11250 JDs. The gross margin measure is important as it expresses the relationship between cash generated from operations and sales. The high average value of the GM of the surveyed farms indicates that these farms can earn cash to pay dividends, suppliers, service debt, and investment in new capital assets. The table also shows that the average values of the benefit-cost ratio (BCR), the rate of return on investment (ROI) and the profitability index (PI) are 1.22, 0.215 and 0.176 respectively. These values indicate that the broiler business is performing well by generating revenues, profits, and cash flow. BCR value suggests that the benefit of broiler farming is higher than the costs by almost $22 \%$, indicating that the investment is a good one. The value of ROI is a net positive, which means that it is worthwhile and suggests that there is a profit generated on broiler investment relative to the amount of money invested. The PI value $(17.6 \%)$ indicates that the investment present value (PV) of the surveyed farms is higher than the initial investment. As the value of the profitability index increases, so does the financial attractiveness of the investment. GM value, as well as the profitability ratios values of the surveyed broiler farms presented in Table 3 , shows that broiler farming is a sustainable and profitable investment. Similar conclusions were derived by Pourkand and Moetamed (2011) and Adeoti and Olawumi (2013).

\subsection{Liquidity measures}

The current ratio (CR) and the Working Capital (WC) to Gross Revenue (GR) ratio were used in this study to measure the surveyed broiler farm's liquidity. The average current farm assets value is (50514 JDs) and the average current farm liabilities value is (20656 JDs). Table 4 shows the results of the analysis of the current ratio (CR) and the Working Capital (WC) to the Gross Revenue (GR) ratio. 
Table 4: Liquidity measures analysis

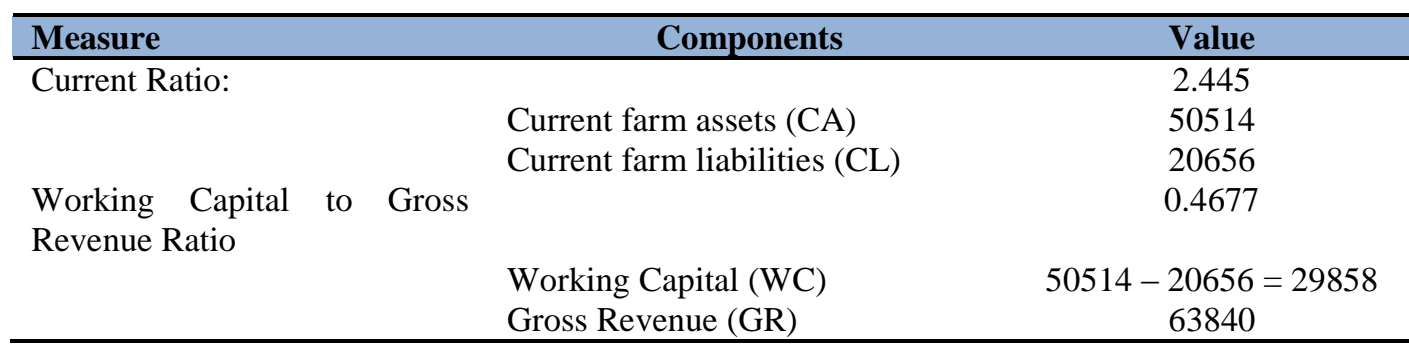

Source: Researchers' computations

Table 4 shows that the average value of the CR of the surveyed farms is 2.445 . This value is higher than 2 and means that the farms are with enough resources to meet their short-term obligations and they can generate sufficient cash to pay off all its debts once they become due. The table also shows that the value of the WC to GR ratio is 0.4677 . This value is more than $30 \%$ (strong according to the commonly accepted ranges for this ratio) indicating that there is sufficient cash is available for the surveyed farms to meet their short-term needs without the use of additional financing. The values of the surveyed broiler farms presented in Table 4 show that broiler farming in Jordan is with a high level of liquidity and not at risk of needing financing indicating a high level of sustainability. Similar results and conclusions were obtained by Fawwaz and Al-Sharafat (2013).

\subsection{Productivity measures}

Feed productivity $(\mathrm{Pf})$ and cost productivity $\left(\mathrm{P}_{\mathrm{c}}\right)$ were used in this study to determine the average productivity of inputs used in broiler production in Jordan. Table 5 shows the results of the analysis of these two measurements.

\section{Table 5: Productivity measures analysis}

\begin{tabular}{llc}
\hline Measure & \multicolumn{1}{c}{ Components and Formula } & Value \\
\hline Feed productivity (Pf): & $\mathrm{Y} \div \mathrm{Q}_{\mathrm{f}}$ & 0.4375 \\
& $\mathrm{Y}=$ Average quantity of broiler meat produced (Tons) & 49.875 \\
& $\mathrm{Q}_{\mathrm{f}}=$ Average quantity of feed consumed/ Y (Tons) & 114 \\
Cost productivity (Pc) & $\mathrm{Y} \div$ ATC & 0.9532 \\
& $\mathrm{Y}=$ Average quantity of broiler meat produced (Kilograms) & 49875 \\
& ATC = Average total costs of production (JDs) & 52320 \\
\hline
\end{tabular}

Source: Researchers' computations

Table 5 shows that the average value of the Pf of the surveyed farms is 0.4375 . That is, $0.4375 \mathrm{~kg}$ of live broiler meat was produced per $\mathrm{kg}$ of feed consumed. This value means that birds are efficiently using feed and have the potential to increase productivity or output. Pf is the opposite of the Feed Conversion Ratio (FCR). Pf is the meat-to-feed ratio, while FCR is the feed-to-meat ratio. FCR is a performance indicator that is commonly used in all types of farming to measure an animal's efficiency in converting feed into increased body mass. It is a ratio or rate measuring the efficiency with which the bodies of broiler or other livestock types convert feed into the desired output. The lower the FCR, or the higher the Pf, the higher the weight gain obtained from the feed, and hence the better efficiency and sustainability. In the broiler industry, the average range of FCR is $(1.8-2.8)$. The FCR of the investigated farms is $(2.6)$ which is within the average range. The findings are higher than those obtained by and Pourkand and Moetamed (2011). The table also shows that the value of $\mathrm{Pc}$ is 0.9532. This value, which is high compared to the results of Hajirahimi and Karimi (2009), Adeoti and Olawumi (2013) and Pourkand and Moetamed (2011) studies, means that the investigated farms are allocating their cost-productivity in an optimum way. 
Cost-allocation is a technique for the reallocation of capital to improve productivity by reducing the amount of a cost item that has been budgeted for and is in the process of expenditure. This will improve performance or reduce costs in the long run and ends in attaining sustainability.

\section{CONCLUSION}

Sustainability is important for any business in any industry but is especially important for agribusinesses. So it is important to understand sustainability and its economic dimension. Profitability, liquidity, and productivity are the three main factors of economic sustainability. The present paper investigated these three major components of economic sustainability in the broiler industry in Jordan. Based on the findings of this study, it could be concluded that the broiler industry in Jordan is economically sustainable. The economic sustainability indicators used in this study to assess profitability, liquidity, and productivity showed that this sector is economically viable and sustainable. Investors in livestock activities in Jordan are advised to invest in the broiler industry as it is with high economic sustainability.

Funding: This study did not receive any specific financial support.

Competing Interests: The authors declared that they have no conflict of interests.

Contributors/Acknowledgement: The authors would like to show gratitude to the Jordanian Department of Statistics, the Jordanian Ministry of Agriculture and Jerash University for their assistance in conducting this study.

Views and opinions expressed in this study are the views and opinions of the authors, Asian Journal of Agriculture and Rural Development shall not be responsible or answerable for any loss, damage or liability etc. caused in relation to/arising out of the use of the content.

\section{References}

Abdurofi, I., Ismail, M., Kamal, H., \& Gabdo, B. (2017). Economic analysis of broiler production in Peninsular Malaysia. International Food Research Journal, 24(4), 1387-1392.

Adeoti, A., \& Olawumi, S. (2013). Economic assessment of raising different broiler strains. Asian Journal of Poultry Science, 7(2), 75-82. doi: 10.3923/ajpsaj.2013.75.82.

Afzal, M., \& Khan, M. (2017). Economic analysis of broiler poultry farms: a case study of District Lower Dir. Sarhad Journal of Agriculture, 33(1), 183-188. doi: http://dx.doi.org/10.17582/journal.sja/2017.33.1.183.188.

Andreoli, M., \& Tellarini, V. (2000). Farm sustainability evaluation: methodology and practice, Agriculture. Ecosystems \& Environment, 77(1-2), 43-52. doi.org/10.1016/s01678809(99)00091-2.

Bachev, H. (2016). Sustainability of farming enterprise - understanding, governance, evaluation. Ekohomika, 2(179), 6-15. doi.org/10.17721/1728-2667.2016/179-2/1.

Bachev, H., Koteva, N., Kaneva, K., Terziev, D., \& Vanev, D. (2016). Sustainability of Bulgarian farms during reformed CAP Implementation. Proceedings of international conference, Fostering agriculture innovation and business opportunities for rural renaissance. October 27-28, Sofia.

Bachev, H. (2017). Sustainability level of Bulgarian farms. Bulgarian Journal of Agricultural Science, 23(1), 1-13.

Bachev, H., \& Peeters, A. (2005). Framework for assessing sustainability of farms. in Farm Management and Rural Planning No 6, Kyushu University, Fukuoka, 221-239.

Bahri, S., Ariffin, A., \& Mohtar, S. (2019). Critical review on food security in Malaysia for broiler industry. International Journal of Academic Research in Business and Social Sciences, 9(7), 869-876.

Bastianoni, S., Marchettini, N., Panzieri, M., \& Tiezzi, E. (2001). Sustainability assessment of a farm in the Chianti area (Italy). Journal of Cleaner Production, 9(4), 365-373. doi.org/10.1016/s0959-6526(00)00079-2. 
Becker, J. (2004). Making sustainable development evaluations work. Sustainable Development, 12, 200-211.

Bélanger, V., Vanasse, A., Parent, D., Allard, G., \& Pellerin, D. (2012). Development of agrienvironmental indicators to assess dairy farm sustainability in Quebec, Eastern Canada. Ecological Indicators, 23, 421-430. doi.org/10.1016/j.ecolind.2012.04.027.

Binder, C, Feola, G., \& Steinberger, J. K. (2010). Considering the normative, systemic and procedural dimension in indicator-based sustainability assessments in agriculture. Environmental Impact Assessment Review, 30(2), 71-81.

Brodt, S., Six, J., Feenstra, G., Ingels, C., \& Campbell, D. (2011). Sustainable agriculture. Nature Education Knowledge, 3(1), 1-10.

Conway, A. (2018). World poultry production at nearly 123 million tons in 2018. Poultry Trends. Retrieved from http://www.poultrytrends.com/2018/index.php.

De Olde, E., Oudshoorn, F., Bokkers, E., Stubsgaard, A., Sørensen, C., \& de Boer, I. (2016a). Assessing the sustainability performance of organic farms in Denmark. Sustainability, 8(957), 1-20. doi.org/10.3390/su8090957

De Olde, E., Oudshoorn, F., Sørensen, C., Bokkers, E., \& de Boer, I. (2016b). Assessing sustainability at farm-level: Lessons learned from a comparison of tools in practice. Ecological Indicators, 66, 391-404. doi.org/10.1016/j.ecolind.2016.01.047.

DoS-Department of Statistics (2017). Agricultural census. Government of Jordan, Amman, Jordan.

DoS-Department of Statistics (2018). Statistical year book. Government of Jordan, Amman, Jordan.

EC (2001). A framework for indicators for the economic and social dimensions of sustainable agriculture and rural development. European Commission.

Fawwaz, T., \& Al-Sharafat, A. (2013). Estimation of resource use efficiency in broiler farms: a marginal analysis approach. Glob. J. Finance and Banking, 7(7), 1-7.

Food and Agriculture Organization (FAO) of the United Nations (2014). Building a common vision for sustainable food and agriculture: Principles and Approaches. Rome- Italy. PP 18-30.

Food and Agriculture Organization (FAO) of the United Nations (2013). SAFA. Sustainability Assessment of Food and Agriculture systems indicators, FAO.

Fuentes, M. (2004). Farms management indicators related to the policy dimension in the European union. OECD Expert Meeting on Farm Management Indicators and the Environment, 8-12 March 2004, New Zealand.

Girardin, P., Bockstaller, C., \& van der Werf, H. (2000). Assessment of potential impacts of agricultural practices on the environment: The AGRO-ECO method. Environmental Impact Assessment, 20, 227-239.

Gómez, J., \& Sanchez, G. (2010): Empirical evaluation of agricultural sustainability using composite indicators. Ecological Economics., 69, 1062-1075.

Hajirahimi, M., \& Karimi, A. (2009). Analyzing productivity of production factors in broiler breeding industry in Kordestan Province. Agricultural Economy and Development, 66, 117.

Hayati, D., Ranjbar, Z., \& Karami, E. (2010). Measuring agricultural sustainability. In: Biodiversity, Biofuels, Agroforestry and Conservation Agriculture. Netherlands. pp. 73100.

Kheiry, H. (2019). Broiler production systems risk management sustainability and feed subsidy policy analysis. IOSR Journal of Agriculture and Veterinary Science (IOSR-JAVS),12(9), 33-44. doi: 10.9790/2380-1209023344.

Latruffe, L., Balcombe, K., \& Davidova, S. (2008a). Productivity change in polish agriculture: an application of a bootstrap procedure to Malmquist indices. Post-Communist Economies, 20(4), 449-460.

MoA - Ministry of Agriculture (2019). Statistical Records. Government of Jordan, Jordan.

Moldan, B., Janouskova, S., \& Hak, T. (2012). How to understand and measure environmental sustainability: Indicators and targets. Ecological Indicators, 17, 4-13. doi.org/10.1016/j.ecolind.2011.04.033. 
Pope, J., Annandale, D., \& Morrison, A. (2004). Conceptualizing sustainability assessment. Environ. Impact Assess. Rev., 24, 595-616. doi.org/10.1016/j.ecolind.2011.04.033.

Pourkand, S., \& Moetamed, M. K., (2011). Analyzing productivity of production factors in broiler industry (a case study: Gilan Province). Agricultural Economic Research 3, 99-116.

Pretty, J. (1999). Regenerating agriculture: Policies and practices for sustainability and selfreliance. Washington: Joseph Henry Press.

Rigby, D., Woodhouse, P., Young, T., \& Burton, M. (2001). Constructing a farm level indicator of sustainable agricultural practice. Ecological Economics, 39(3), 463-478.

Sauvenier, X., Valekx, J., Van Cauwenbergh, N., Wauters, E., Bachev, H., Biala, K., Bielders, C., Brouckaert, V., Garcia-Cidad, V., Goyens, S., Hermy, M., Mathijs, E., Muys, B., Vanclooster, M., \& Peeters, A. (2005). Framework for assessing sustainability levels in Belgium agricultural systems - SAFE, Belgium Science Policy, Brussels.

UN (2015). Transforming our world: the 2030 Agenda for Sustainable Development. United Nations Resolution A/RES/70/1 of 25 September 2015.

Warhurst, A. (2002). Sustainability indicators and sustainability performance management. Report to the Project: Mining, Minerals and Sustainable Development (MMSD). Warwick, England: International Institute for Environment and Development (IIED). http://www.iied.org/mmsd/mmsdpdfs/sustainability/indicators.pdf.

Werf, V., \& Petit, J. (2002). Evaluation of the environmental impact of agriculture at the farm level: A comparison and analysis of 12 indicator-based methods. Agriculture, Ecosystems and Environment, 93, 131-145. doi.org/10.1016/s0167-8809(01)00354-1.

Wilkin, J. (2010). Multifunctional agriculture. Research directions, methodological foundations and practical implications. IRWiR PAN, Warsaw, Poland.

Wrzaszcz, W., \& Zegar, J. S. (2016). Economic sustainability of agricultural holdings in Poland in the context of their environmental impact. European Journal of Sustainable Development, 5(4), 497-508. doi: 10.14207/ejsd.2016.v5n4p497.

Yamane, T. (1967). Statistics: An Introductory Analysis. 2nd Edition, Harper and Row, New York.

Zhen, L., \& Routray, J. (2003). Operational indicators for measuring agricultural sustainability in developing countries. Environmental Management, 32(1), 34-46. doi.org/10.1007/s00267003-2881-1. 